\title{
Rancang Bangun Sistem Pembelajaran Tenses Berbasis Macromedia Flash 8
}

\author{
R. Arum, SP, Herlinawati, Afis Pratama \\ Jurusan Elektro, Fakultas Teknik, Universitas Lampung \\ J1. Sumantri Brojonegoreo No.1, Bandar Lampung \\ afis_pratama@yahoo.com
}

\begin{abstract}
Abstrak
Pada penelitian ini telah dirancang sistem pembelajaran tenses yang dibuat dengan menggunakan software Macromedia Flash 8. Sistem ini bertujuan untuk meningkatkan antusiasme belajar para siswa dalam upaya memahami Tenses Bahasa Inggris. Di dalam sistem pembelajaran ini terdapat 16 materi tenses, sejumlah soal latihan, dan 3 macam test yang disajikan secara menarik. Sistem ini dapat digunakan juga oleh staf pengajar untuk menguji kemampuan para siswa dalam pemahaman tenses. Staf pengajar yang berperan sebagai admin juga dapat memanfaatkan interface program untuk meng-update soal-soal yang telah ada sebelumnya dan akan tersimpan dalam database PHP.
\end{abstract}

Kata Kunci: Sistem pembelajaran, tenses, macromedia flash 8, PHP

\begin{abstract}
In this study, the tenses learning system will be designed by using Macromedia Flash 8 software. This system aims to enhance the enthusiasm of learning from students in an effort to understand the English tenses. In this learning system, there are 16 tenses material, some exercises, and 3 kinds of tests are presented in interesting way. This system can also be used by teacher to test the ability of the students in understanding tenses. Teacher who have role as the admin can also use the program interface to update the problems that have been there before and will be stored in the database PHP.
\end{abstract}

Keywords: learning system, tenses, Macromedia Flash 8, PHP.

\section{Pendahuluan}

para pelajar. Karena di dalam buku-buku pelajaran pada bab-bab tertentu ada pokok bahasan yang pembahasannya harus bertitik tolak pada tenses, seperti conditional clause, subjunctive, direct and indirect speech, tag question dan passive voice. Bila penguasaan tenses belum memadai, niscaya para pelajar akan sulit memahaminya.

Saat ini penggunaan Macromedia Flash sebagai software pembelajaran sudah banyak digunakan. Yang paling sering adalah pada bidang Fisika, karena Macromedia Flash mampu membuat animasi interaktif sehingga Fisika akan mudah dipahami dan terlihat menarik. Namun pada bidang Bahasa Inggris penggunaan Macromedia Flash masih jarang dijumpai, terutama yang dikhususkan pada bidang tenses.

Pada penelitian ini, akan dibuat sebuah sistem
Penguasaan tenses adalah salah satu faktor penting bagi pembelajar bahasa Inggris, khususnya pembelajaran Tenses berbasis Macromedia Flash 8. Aplikasi ini diharapkan dapat meningkatkan antusias pelajar maupun mahasiswa dalam belajar Bahasa Inggris khususnya dalam pemahaman tenses, karena disajikan dengan tampilan yang menarik di dalam sebuah komputer. Sehingga user dapat dengan mudah mempelajarinya serta menjawab soal-soal Bahasa Inggris yang ada di dalam aplikasi ini.

\section{Tinjauan Pustaka}

\subsection{Tenses}

Kata tense dalam bahasa Inggris berasal dari bahasa latin tempus yang berarti waktu. Tenses membicarakan tentang waktu yang menunjukkan kapan terjadinya suatu kejadian atau peristiwa, 
kelanjutan, dan selesainya peristiwa tersebut. Jadi English Tenses pada dasarnya membicarakan tentang waktu terjadinya suatu kejadian atau peristiwa. Secara umum suatu kejadian bisa terjadi di waktu sekarang (present), di waktu lampau (past) atau yang akan terjadi di waktu yang akan datang (future).

\subsection{SISTEM}

Sistem merupakan suatu kesatuan yang terjadi atas sejumlah subsistem-subsistem yang berinteraksi untuk mencapai suatu tujuan tertentu (Jogiyanto. H, 2004 : 683). Komponen atau subsistem dalam suatu sistem tidak dapat berdiri sendiri-sendiri sehingga komponen atau subsistem harus saling berinteraksi dan saling berhubungan membentuk satu kesatuan sehingga tujuan atau sasaran sistem tersebut dapat tercapai.

Suatu sistem biasanya mempunyai dua tujuan. Pertama, suatu sistem bermaksud mencapai tujuan yang bisaanya dihubungkan ruang lingkup yang luas dan sasaran dalam ruang lingkup yang lebih sempit. Kedua, suatu sistem bermaksud untuk mencapai sasaran, di mana sistem merupakan bagian atau subsistem dari bisnis. Akan tetapi seringkali tujuan dan sasaran digunakan bergantian dan tidak dibedakan.

\subsection{MACROMEDIA FLASH 8}

Macromedia Flash merupakan salah satu software animasi yang sudah tidak asing lagi bagi kebanyakan orang yang berkecimpung dalam pembuatan program animasi. Software ini mempunyai banyak keunggulan dibandingkan dengan software animasi lainnya diantaranya adalah program yang berorientasi objek (OOP), mampu mendesain gambar berbasis vector, dapat dipergunakan sebagai software pembuat situs WEB, dan banyak keunggulan lainnya. Dibandingkan dengan versi sebelumnya yaitu versi 4.0, 5.0, MX, Macromedia Flash Professional 8 ini mempunyai beberapa kemampuan tambahan di antaranya mampu menjalankan audio dalam bentuk file mp3.

\section{Area Kerja}

Tampilan antarmuka atau area kerja Flash terdiri atas beberapa bagian, seperti terlihat pada gambar 1.

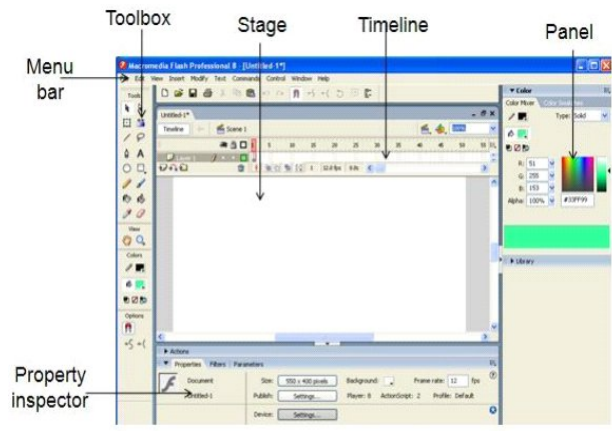

Gambar 1. Area kerja Flash

Keterangan:

STAGE : sebuah area untuk membuat animasi . Stage dpt diibaratkan seperti sebuah kanvas untuk mengkomposisi frame ñframe sehingga membentuk sebuah movie.

TIMELINE PANEL : sebuah panel yang digunakan untuk mengatur sebuah movie. Pada panel ini kita dapat mengatur kapan sebuah objek muncul dan kapan sebuah objek hilang

TOOLBOX: tempat tool-tool yg sering digunakan utk membuat dan memodifikasi objek, membuat teks, mengolah warna, dan mengatur stage.

PROPERTY INSPECTOR: panel yg digunakan utk mengubah atribut-atribut objek. Tampilan property inspector selalu berubah tergantung dari objek yang kita pilih.

\subsection{Database}

Database digunakan untuk mengelola data dalam jumlah besar, misalnya data penduduk dalam suatu negara. Database mengandung obyek-obyek yang digunakan untuk mewakili, menyimpan, dan mengakses data dengan mudah. Tanpa database, programmer akan membuat procedure-procedure yang rumit untuk memanipulasi data.

Database merupakan kumpulan dari data yang saling berhubungan dengan yang lainnya, tersimpan di perangkat keras komputer dan digunakan perangkat lunak untuk memanipulasinya. Database merupakan salah satu komponen yang penting dalam sistem informasi, karena merupakan basis dalam menyediakan informasi bagi para pemakai. Penerapan database dalam sistem informasi disebut dengan database system.

Sistem database adalah suatu sistem informasi yang mengintegrasikan kumpulan dari data yang saling berhubungan satu dengan yang lainnya dan membuatnya tersedia untuk beberapa aplikasi yang bermacam-macam di dalam suatu organisasi. Dengan sistem database ini tiap-tiap orang atau bagian dapat memandang database dari beberapa sudut pandang yang berbeda. Bagian kredit dapat 
memandangnya sebagai data piutang, bagian penjualan dapat memandangnya sebagai data penjualan. Semua terintegrasi dalam sebuah data yang umum. Berbeda dengan sistem pengolahan dala tradisional, sumber data ditangani sendirisendiri untuk tiap aplikasinya.

\subsection{PHP}

PHP adalah bahasa server side scripting yang menyatu dengan HTML untuk membuat halaman web yang dinamis. Maksud dari istilah server side scripting adalah sintaks dan perintah yang diberikan akan sepenuhnya dijalankan di server tetapi disertakan pada dokumen HTML. Pembuatan web sendiri merupakan kombinasi antara PHP sebagai bahasa pemrograman dan HTML sebagai pembangun halaman web. Ketika seorang pengguna internet akan membuka suatu situs yang menggunakan fasilitas server side scripting PHP, terlebih dahulu server yang bersangkutan akan memproses semua perintah PHP di server lalu mengirimkan hasilnya dalam format HTML ke web browser pengguna internet tadi. Seorang pengguna internet tidak dapat melihat kode program yang ditulis dalam PHP sehingga keamanan dari halaman web menjadi lebih terjamin.

PHP bersifat open source, sehingga untuk mendapatkannya kita tidak perlu membayar lisensi. Dasar pertimbangan untuk mengembangkan kemampuan pemrograman berorientasi objek pada PHP adalah dengan melihat perkembangan aplikasi web sebagai sebuah platform yang terus meluas dengan cepat sehinggga aplikasi web yang dibangun juga menjadi semakin besar, rumit, dan kompleks. Aplikasi web telah diimplementasikan mulai dari tingkatan yang paling sederhana seperti berita online hingga ke tingkatan enterprise seperti aplikasi online banking.

PHP dapat mengirim HTTP header, dapat mengeset cookies, mengatur authentication. PHP menawarkan koneksitas yang baik dengan beberapa basis data, antara lain Oracle, Sybase, mSQL, MySQL, Solid, PostgreSQL, Adabas, Velocis, dBase dan semua database berinterface ODBC. PHP juga berintegrasi dengan beberapa external library sehingga pengguna dapat membuat dokumen PDF.

\section{Metetode Penelitian}

\subsection{Alat dan bahan}

Alat dan bahan yang digunakan pada penelitian ini antara lain:

1. Satu unit komputer.

2. Software Macromedia Flash 8.

3. Browser Mozilla Firefox.

4. XAMPP sebagai localhost
5. Materi dan contoh dari berbagai tenses dalam Bahasa Inggris.

\subsection{Deskripsi Umum Sistem}

Proses pengerjaan penelitian ini dapat dilihat pada gambar 2. Dalam flowchart pada gambar 2 terlihat proses-proses dalam pembuatan penelitian ini secara urut, yaitu analisis kebutuhan, merencanakan dan mendesain program, uji internal yang terdiri dari uji ahli materi dan uji ahli media pembelajaran, revisi program, uji eksternal kepada responden, revisi hasil uji kepada responden, sampai terciptanya program akhir.

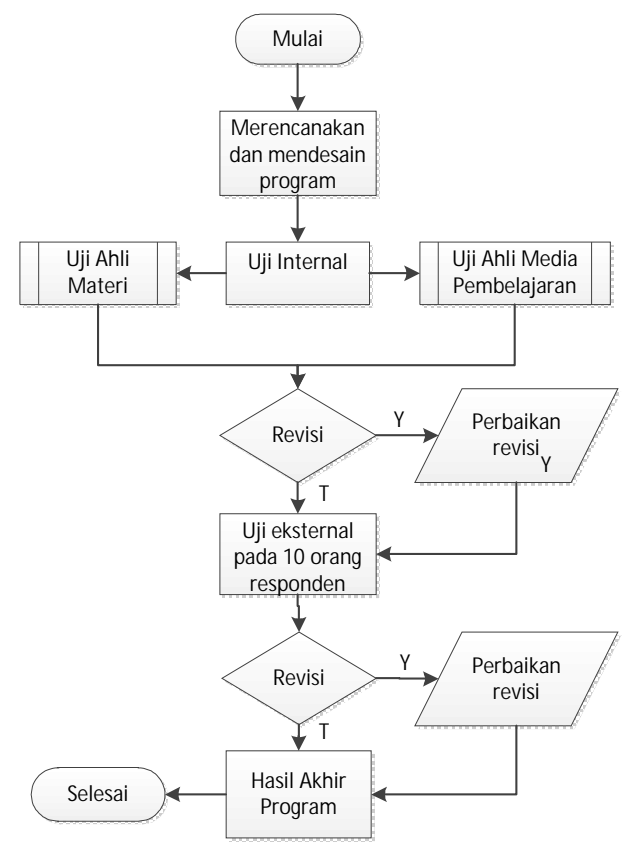

Gambar 2. Flowchart Proses Pembuatan Penelitian

Secara umum penelitian ini terdiri atas lima buah menu utama yaitu:

a) Definisi Tenses: merupakan menu untuk menampilkan definisi dari tenses.

b) Present, Past, Future, Past Future: merupakan menu yang di dalamnya terdapat lima buah kategori menu lagi yaitu empat buah menu subtenses dan satu menu latihan soal sesuai dengan kategori tenses yang dipilih. Terdapat 10 soal di dalam menu latihan per kategori tenses.

c) Test merupakan menu yang di dalamnya terdapat simulasi test sebanyak tiga macam level test yaitu basic dan intermediate. Dalam level test basic dan intermediate terdapat dua macam test lagi yaitu pre test yang terdiri dari 10 soal dan post test yang terdiri atas 20 soal. Sedangkan pada menu final test merupakan 
menu yang disediakan interface untuk admin agar dapat mengupdate soal-soal. Sistem dapat merekam nama user dan sistem dapat menampilkan skor yang didapat user. User juga dapat melihat pembahasan dari hasil test yang telah di lakukan dengan melalui menu pembahasan.

d) About: merupakan menu yang menampilkan tentang sistem yang dibuat dan biodata pembuat sistem.

e) Read Me: merupakan menu yang menjelaskan tentang bagaimana menggunakan program ini.

\subsection{PROSEDUR KERJA}

Metode yang digunakan dalam pembuatan penelitian ini menggunakan metode waterfall.

Kebutuhan Sistem. Komponen - komponen yang dibutuhkan untuk merancang program sistem pembelajaran tenses ini terdiri atas:

a. Komponen Perangkat Keras (Hardware) Peralatan yang dibutuhkan untuk mendukung jalannya penelitian ini adalah satu unit komputer dengan sistem operasi Windows XP Service Pack 3, Prossesor Intel Pentium $(2.00 \mathrm{GHz})$, dan RAM 1GB.

b. Komponen Perangkat Lunak (Software) Software yang digunakan untuk pembuatan sistem dalam penelitian ini menggunakan Macromedia Flash Professional 8.

Kebutuhan Software. Penulis menggunakan software Macromedia Flash 8 dalam merancang program sistem pembelajaran ini. Dalam software terdapat fitur-fitur yang dapat digunakan untuk membuat pembelajaran secara interaktif.

Perancangan Desain Arsitektur. Dalam bagian ini, penulis merencanakan tampilantampilan program yang akan dibuat. Penulis merencanakan desain-desain di setiap scene-nya.

Pengkodean. Untuk dapat dimengerti oleh mesin, dalam hal ini adalah komputer, maka desain tadi harus diubah bentuknya menjadi bentuk yang dapat dimengerti oleh mesin, yaitu ke dalam pemrograman melalui proses perancangan menggunakan software Macromedia Flash 8. Tahap ini merupakan implementasi dari tahap desain yang secara teknis nantinya dikerjakan oleh penulis.

Pengujian. Pada tahap ini, terdapat dua macam uji coba yaitu ujicoba internal dan ujicoba eksternal. Ujicoba internal diujikan kepada ahli bahasa Inggris dan ahli media pembelajaran, setelah diujicoba dengan kedua ahli tersebut, penulis mengharapkan adanya koreksi dan masukan yang nantinya akan menjadikan program yang dibuat menjadi lebih baik. Sedangkan ujicoba internal diujikan kepada sepuluh orang responden dari berbagai kalangan.

Perawatan. Perawatan yang dilakukan adalah dengan memeriksa program pada area kerja software Macromedia Flash 8 dan memperbaharui materi jika terdapat materi yang lebih baik dibandingkan materi yang telah tertuang dalam program sebelumnya.

\section{Hasil dan Pembahasan}

\subsection{Hasil Akhir}

Produk sistem pembelajaran tenses ini memiliki menu utama yaitu, definisi tenses, present, past, future, past future, read me, about, dan test seperti yang terlihat pada gambar 3 .

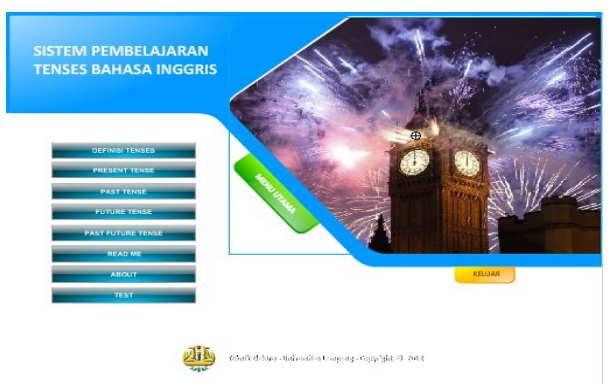

Gambar 3. Tampilan Menu Utama

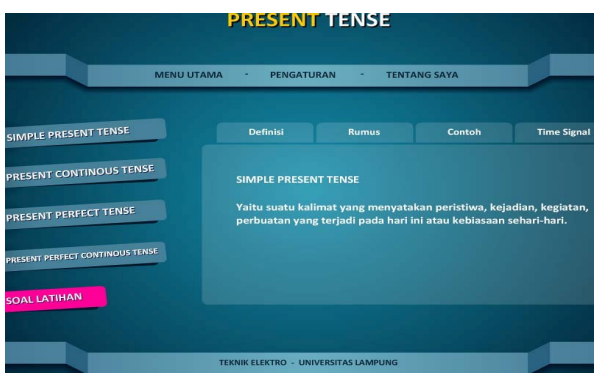

Gambar 4. Materi Program

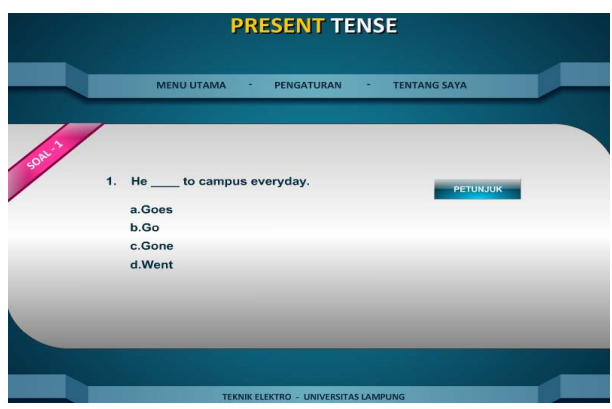

Gambar 5. Menu Latihan 
Pada gambar 4 terlihat di masing-masing submenu dari menu simple present tense terdapat empat buah menu lagi yaitu menu definisi, menu rumus, menu contoh dan menu time signal. Masingmasing keempat menu tersebut berisikan materi sesuai dengan nama judul menu masing-masing.

Gambar 5 adalah menu soal latihan yang pertanyaannya meliputi soal-soal kategori present tense. Dalam latihan ini terdapat 10 buah pertanyaan. Pada setiap pertanyaan, penulis memberikan petunjuk atau bantuan yang bertujuan untuk membantu user dalam menjawab soal apabila user merasa sulit dalam menjawab soal tersebut. Penilaian dalam latihan soal ini adalah setiap soal bernilai 10 poin, jadi apabila user dapat menjawab semua soal dengan benar user akan mendapatkan nilai 100. Nilai dari hasil latihan akan ditampilkan pada akhir sesi latihan.

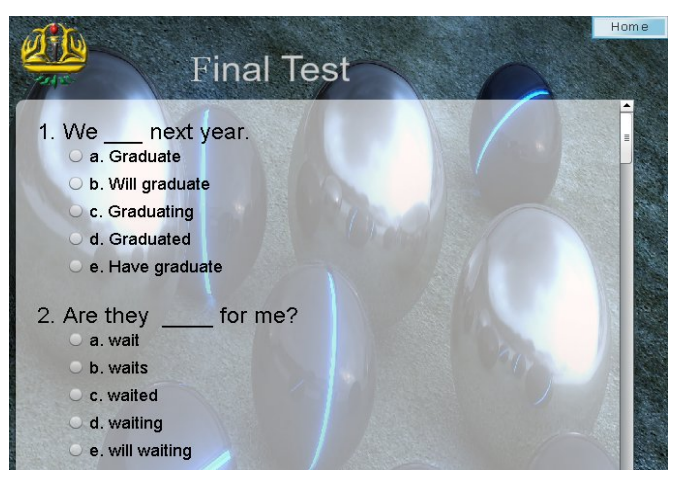

Gambar 6. Final Test

Gambar 6 merupakan tampilan dari menu final test. Dalam menu ini admin dapat mengupdate data soal dan data siswa/user.

\subsection{Interface Update Data Soal}

Gambar 7 merupakan tampilan dari menu administration panel. Dalam menu tersebut terdapat menu untuk mengupdate soal dan data user yang hanya dapat diakses oleh admin saja.

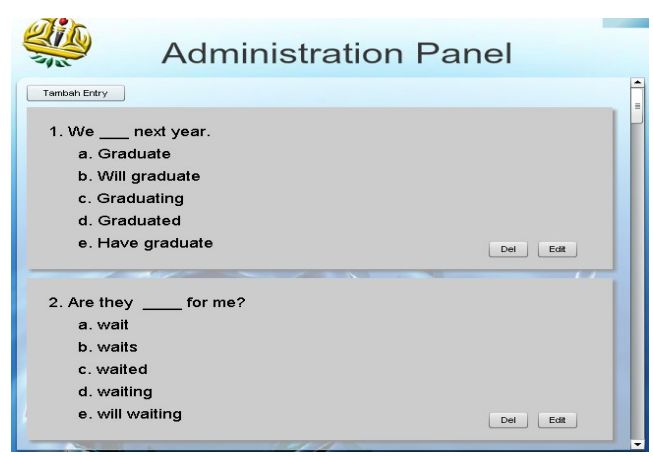

Gambar 7. Administration Panel

\subsection{Database Soal}

Gambar 8 merupakan tampilan database pertanyaan pada menu php MyAdmin. Soal baru yang telah dibuat pada interface administration panel akan tersimpan pada database seperti pada gambar 4.

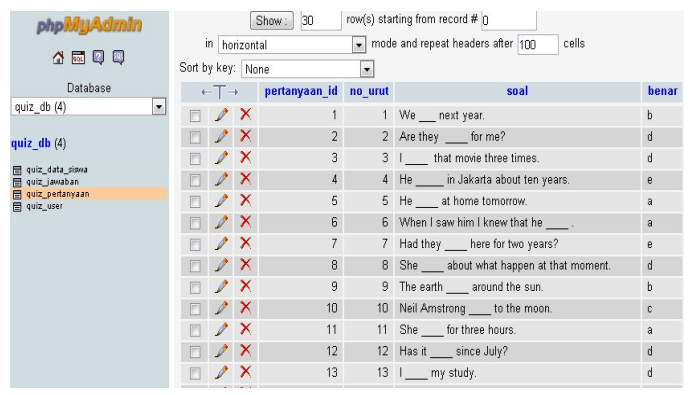

Gambar 8. Database Pertanyaan

\subsection{Pengujian}

Dari hasil pengujian terhadap 10 orang responden, diperoleh perbandingan rata-rata nilai sebelum dan sesudah menggunakan program sistem pembelajaran tenses. Jika diambil rata-rata peningkatannya adalah sebesar $25 \%$.

\section{Kesimpulan}

Dari hasil dan pembahasan pada penelitian ini, dapat diambil beberapa simpulan sebagai berikut.

1. Dari hasil angket yang dibagikan kepada responden, program sistem pembelajaran tenses berbasis Macromedia Flash 8 berhasil meningkatkan kemampuan 
penguasaan tenses bahasa Inggris responden sebesar $25 \%$.

2. Lebih dari $50 \%$ responden menyatakan dengan pembuatan sistem pembelajaran berbasis macromedia flash ini, dapat meningkatkan antusiasme mereka karena disajikan dengan desain yang menarik.

3. Perancangan dan pembuatan sistem pembelajaran tenses ini telah berhasil dilakukan menggunakan Metode Waterfall.

4. Sistem pembelajaran tenses ini masih terdapat kekurangan seperti belum mampu mengacak distribusi soal yang disajikan kepada user.

\section{DAFTAR PUSTAKA}

1) Chandra, 2005, Menu Interaktif Flash $M X$ 2004. Maxikom.

2) Chandra, 2005, 8 Aplikasi Populer Flash MX 2004. Maxikom.

3) Chandra. 2003. Beranimasi Ria dengan Flash MX. Maxikom

4) Gregorius, Agung. 2007. 6 Aplikasi Ampuh Flash Professional 8. Jubilee Enterprise

5) Wijaya, Didik dan Parulian, Andar. 2003, Macromedia Flash MX dengan Action Script. PT. Elex Media Komputindo.

6) Akerlund, Alfred. 1911. The Definite Tenses in English. Cambridge

7) J.S, Hartanto. 2003. Tata Bahasa Inggris. Indah Publisher

8) Suyanto M. Multimedia Alat Untuk Meningkatkan Keunggulan Bersaing.

9) IJCSI. 2010. A Comparisson Between Five Models of Software Engineering. www.IJCSI.org, diakses 28 Juli 2012.

10) Pramono, Gatot. 2007. Aplikasi Component Display Theory dalam Multimedia dan Web Pembelajaran. Departemen Pendidikan Nasional Pusat Teknologi Informasi dan Komunikasi Pendidikan.

11) Nugroho, Widyo. 2003. Makalah Pelatihan Penulisan Program Multimedia. Universutas Gunadarma.

12) Herpratiwi. 2009. Teori Belajar dan Pembelajaran. Universitas Lampung.

13) Allessi, Stephen, M. 1991. Computer Based Instructional Method and Development. Prentice Hall. New Jersey.

14) Arsyad, Azhar. 2005. Media Pembelajaran. PT. Raja Grafindo Persada. Jakarta

15) Brooks, Nelson. 1964. Language and Language Learning: Theory and Practice. http://books.google.co.id. Diakses 20 Juni 2012.
16) Walter, Dick and Lou Carey. 2001. The Systematic Design of Instruction. Fifth Edition. Longman

17) Mardika, I Nyoman. Pengembangan Multimedia dalam Pembelajaran Kosakata Bahasa Inggris. http//mardikanyom.tripod.com/Multimedia. pdf, diakses 20 Juni 2012.

18) Materi dan contoh soal UN Tenses. http://www.belajarbahasainggrisyuk.com/ materi-dan-contoh-soal-un-tenses/, diakses 15 Mei 2012

19) Gramatical Tenses. http://en.wikipedia.org/wiki/Grammatical t ense. diakses 15 Mei 2012.

20) Mufli. 2009. 16 Tenses Bahasa Inggris. http://tensesbahasainggris.com/16-tensesbahasa-inggris-sudah-siap-saji. diakses 12 Mei 2012.

21) Listinasari. 2010. Pengembangan Computer-Assisted Language Learning (CALL) Bahasa Inggris Kelas XI SMA Negeri 1 Pagelaran. Tesis. Universitas Lampung. Lampung.

22) Higgins, John and Tim Johns. 1984. Computer in Language Learning. Great Britain. http://books.google.co.id/books.language+ needs+repetitions, diakses 21 Juni 2012.

23) Robyler.2006. Intergrating Educational Technology into Teaching. Perason Prentice Hall. http://books.google.co.id/books?id=Ou6pa p0fMC\&pg $=$ PA $82 \& d q=$ drill + and + practice +in+learning+english, diakses 29 Juni 2012. 